[Article]

\title{
腿基嘧啶酮四氢键二茂铁二聚体：电子相互作用的调控
}

\author{
王素敏 赵线娜 王奇观 ${ }^{*}$ 郭 浩 李金华 张文慧 \\ (西安工业大学材料与化工学院, 陕西省光电功能材料与器件重点实验室, 西安 710032)
}

\begin{abstract}
摘要: 以腿基嘧啶酮四重氢键为桥联单元, 组装了二茂铁同体二聚体 $(1 \cdot 1)$ 。电化学实验显示 $1 \cdot 1$ 中两个等同 的二茂铁基团的氧化还原电位差值 $(\Delta E)$ 达 $260 \mathrm{mV}$, 说明 $1 \cdot 1$ 中两个二茂铁基团间通过四氢键发生了显著的 电子相互作用。在 $1 \cdot 1 / \mathrm{CHCl}_{3}$ 中逐步加入 0.5、1 和 2 等摩尔的 $\mathrm{CF}_{3} \mathrm{COOH}$ 时, 由于腿基嘧啶酮四氢键的逐步 解离, 二茂铁间的电子相互作用强度逐渐减弱, 其 $\Delta E$ 从 $260 \mathrm{mV}$ 逐步减小至 $150 、 100$ 和 $0 \mathrm{mV}$, 此时再加 入三乙胺又可以使电子相互作用逐步恢复至初始状态, 说明通过加入质子酸、碱可有效调控四氢键体系中发 色团间通过氢键的电子相互作用。
\end{abstract}

关键词: 嫝基嘧啶酮; 四氢键; 电子相互作用; 调控; 二茂铁

中图分类号: 0648

\section{Ureidopyrimidinone Quadruple Hydrogen-Bonded Ferrocene Dimer: Control of Electronic Communication}

\author{
WANG Su-Min ZHAO Rong-Na WANG Qi-Guan* GUO Hao LI Jin-Hua ZHANG Wen-Hui \\ (Shaanxi Key Laboratory of Photoelectric Functional Materials and Devices, School of Materials and Chemical Engineering, \\ Xi'an Technological University, Xi'an 710032, P. R. China)
}

\begin{abstract}
A ferrocene homodimer was assembled via the ureidopyrimidinone quadruple hydrogen-bonded module in this paper. Remarkable electronic communication was found between the two ferrocene centers across the ureidopyrimidinone bridge in chloroform. The separation between the two redox potentials $(\Delta E)$ of the ferrocenyl moieties was $260 \mathrm{mV}$. Upon protonation of the hydrogen-bonded bridge by successive addition of $0.5,1$, and 2 equivalents of trifluoroacetic acid, the extent of the electronic communication between the subunits gradually lowered, with $\Delta E$ decreasing to 150,100 , and $0 \mathrm{mV}$, respectively, because of the stepwise dissociation of the pyrimidinone hydrogen-bonded bridge. This phenomenon is reversible, and the initial voltammogram can be recovered stepwise by successive addition of triethylamine, demonstrating effective control of the electronic communication between two ferrocene centers.
\end{abstract}

Key Words: Ureidopyrimidinone; Quadruple hydrogen bonding; Electronic communication; Control; Ferrocene

\section{Introduction}

Ferrocene dimers and oligomers have attracted enormous in- terests in the past years due to their potential use as good candidate for molecular wire ${ }^{1,2}$. In ferrocene dimers, electronic communi-

Received: November 9, 2015; Revised: December 24, 2015; Published on Web: January 4, 2016.

*Corresponding author. Email: qiguanwang@163.com; Tel: +86-29-86173324.

The project was supported by the National Natural Science Foundation of China (21103133), Scientific Research Foundation for the Returned Overseas Chinese Scholars, Ministry of Education, Natural Science Foundation of Shaanxi Province, China (2015JM5224), Shaanxi Provincial Education Department Program, China (2013JK0678), and National Training Programs of Innovation and Entrepreneurship for Undergraduates, China (201510702030).

国家自然科学基金(21103133), 教育部留学归国科研启动基金, 陕西省自然科学基金(2015JM5224), 陕西省教育厅科研计划项目(2013JK0678) 和大学生创新创业训练计划项目(201510702030)资助

(C) Editorial office of Acta Physico-Chimica Sinica 
cation between $\mathrm{Fe}(\mathrm{II})$ and $\mathrm{Fe}(\mathrm{III})$ sites in the mixed valence could form the basis for well-defined molecular devices of energy conversion, sensing, or molecular electronics, thus promoting continued research in this direction ${ }^{3-5}$. A variety of $\pi$ and $\sigma$ bonds have been generally chosen as bridges of redox centers to support the electronic communication process. It is suggested that electronic communication was strongly affected by geometry, electronic structure, and length of the linkers between redox centers ${ }^{6-9}$, and extensive electron delocalization is the critical factor for efficient electronic communication over large distance.

In addition to pursuing large extent of electronic communication and understanding the mechanism, control of the electronic communication between two redox centers is also attractive in view of the potential application as intelligent switches on molecular wires and molecular machines ${ }^{10-14}$. A few reports have been found on the control of electronic communication by an external stimuli such as protoation. Alvarez and $\mathrm{Kaifer}^{15}$ prepared a dinuclear ferrocene compound containing a $-\mathrm{CH}_{2}-\mathrm{N}(\mathrm{R})-\mathrm{CH}_{2}-$ bridge, which exhibits a moderate degree of electronic communication between the ferrocene subunits, and it can be disrupted by protonation or N-methylation of the bridge's tertiary nitrogen atom. Sasaki et al. ${ }^{16}$ utilized a 2,5-dimercapto-1,3,4-triadiazolate as a bridge to conduct the electronic communication of dinuclear ruthenium(II) which can be quenched by protonation of the bridge unit.

After it was realized that hydrogen bonds can also mediate the electronic coupling between redox sets behaving as $\sigma$ and $\pi$ bonds ${ }^{17}$, the electronic communication through hydrogen-bonded bridges had also been emphasized ${ }^{18-20}$. In 2006, Kaifer et al. ${ }^{21}$ reported large extent of electronic communication occurred between two identical ferrocene centers with separation distance more than $0.1 \mathrm{~nm}$ linked by AADD (A: hydrogen bond acceptor, D: hydrogen bond donor) quadruple hydrogen-bonded motif similar to the well-known ureidopyrimidinone ${ }^{22,23}$. Compared with covalent bonds, hydrogen bonds are more sensitive to the external stimuli, such as solvent, $\mathrm{pH}$, and temperature, so the control of electronic communication via hydrogen bonding is more desired. However, it was scarcely reported up to now. In this paper, ureidopyrimidinone modified ferrocene derivative 1 , in which the ferrocene group was directly linked to the 6-position carbon atom of pyrimidinone heterocycle, was synthesized. Resulted from the great binding strength and self-complementary characteristic of 2-ureido-4[1H]-pyrimidinone AADD hydrogen-bonded module developed by Meijer and co-workers ${ }^{22,23}$, stable hydrogen-bonded dimer $\mathbf{1} \cdot \mathbf{1}$ (Fig.1) was formed in apolar solvents such as $\mathrm{CHCl}_{3}$ and $\mathrm{CH}_{2} \mathrm{Cl}_{2}$. Electrochemical results proved that in $\mathrm{CHCl}_{3}$ the 2ureido- $4[1 H]$-pyrimidinone-bridged ferrocene dimer $\mathbf{1} \cdot \mathbf{1}$ exhibits a remarkable level of electronic communication across the hydrogen-bonded interface. More importantly, the level of electronic communication of ferrocene dimer $\mathbf{1} \cdot \mathbf{1}$ can be reversibly controlled by the stepwise addition of $\mathrm{CF}_{3} \mathrm{COOH} /$ triethylamine $\left(\mathrm{Et}_{3} \mathrm{~N}\right)$, through the protonation/deprotonation of pyrimidinone unit in compound 1.

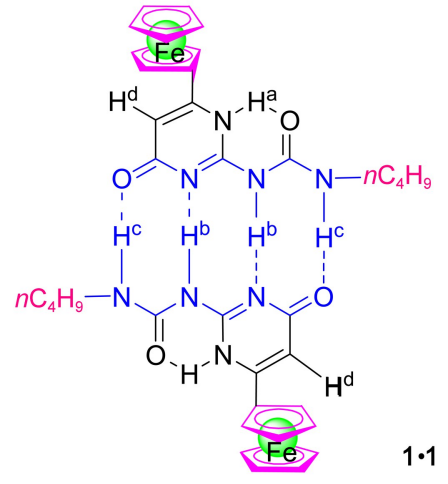

Fig.1 2-Ureido-4[1H]-pyrimidinone quadruple hydrogenbonded ferrocene dimer $1 \cdot 1$

\section{Experimental}

\subsection{Apparatus, materials and measurements}

${ }^{1} \mathrm{H}$ NMR spectra were recorded on a Bruker Avance dpx $400 \mathrm{MHz}$ instruments (Germany), using tetramethylsilane (TMS) as internal standard. UV-Vis spectra were obtained using a Shimadzu 1901 spectrophotometer (Japan). Mass spectra were obtained on Bruker APEX II spectrometers (Germany). Elemental analyses were performed on a Carlo Erba 1106 elemental analyzer (Italy). Electrochemical measurements were carried out on $\mathrm{CHI} 660 \mathrm{C}$ electrochemical workstation in $\mathrm{CHCl}_{3}$ containing $0.1 \mathrm{~mol} \cdot \mathrm{L}^{-1}$ ammonium perchlorate as the supporting electrolyte, with Pt slide auxiliary electrode and Pt slide working electrode, saturated calomel electrode (SCE) reference electrode.

$\mathrm{NaH}$ (52\% mineral oil dispersion), acetylferrocene (95\%), diethyl carbonate $(99 \%)$, guanidinium carbonate $(99 \%)$, ammonium perchlorate $(99 \%)$ were purchased from Aldrich and used as received. Tetrahydrofuran (THF), $\mathrm{CHCl}_{3}(99 \%)$, triethylamine $\left(\mathrm{Et}_{3} \mathrm{~N}, 99 \%\right)$, and pyridine (99\%) were purchased from Aladdin. Anhydrous THF was obtained by distillation from sodium/benzophenone. Pyridine, $\mathrm{Et}_{3} \mathrm{~N}$, and $\mathrm{CHCl}_{3}$ were heated under reflux with $\mathrm{CaH}_{2}$ for $3 \mathrm{~h}$, and then distilled. The other reagents and solvents with analytical grade were obtained from Sinopharm Chemical Reagent Co., Ltd. and used as received.

\subsection{Synthesis}

\subsubsection{Ethyl 3-ferrocenyl-3-oxopropionate (2)}

A suspension of $\mathrm{NaH}(52 \%$ on dispersion oil, $1.85 \mathrm{~g}, 40.0$ $\mathrm{mmol})$ and diethyl carbonate $(3.6 \mathrm{~mL}, 29.7 \mathrm{mmol})$ in dry THF $(100 \mathrm{~mL})$ was refluxed under an argon atmosphere. A solution of acetylferrocene $(2.74 \mathrm{~g}, 12.0 \mathrm{mmol})$ in $10 \mathrm{~mL}$ of dry THF was then added dropwise over $2 \mathrm{~h}$ and the mixture was refluxed overnight. The dense suspension was carefully poured into a mixture of saturated aqueous of $\mathrm{NH}_{4} \mathrm{Cl}, 5 \%$ aqueous $\mathrm{HCl}$, and ice with volume ratio of them being $1: 1: 1$, and extracted with $\mathrm{CHCl}_{3}$. The organic layer was washed with saturated aqueous $\mathrm{NH}_{4} \mathrm{Cl}$, then dried by $\mathrm{MgSO}_{4}$ for $12 \mathrm{~h}$, and then concentrated to dryness. The crude was purified by performing column chromatography on silica gel $\left(\mathrm{CHCl}_{3} /\right.$ petroleum, $\left.5: 1(\mathrm{~V} / \mathrm{V})\right)$ to afford the product in $54 \%$ yield as red brown oil. ${ }^{1} \mathrm{H} \mathrm{NMR}\left(\mathrm{CDCl}_{3}, 400 \mathrm{MHz}\right) \delta_{\mathrm{H}}: 4.79$ (br. s, 2H, Fc), 4.56 (br. s, 2H, Fc), 4.29 (br. s, 5H, Fc), 4.25-4.18 
(q, $\left.2 \mathrm{H}, J=8.0 \mathrm{~Hz},-\mathrm{COOCH}_{2}-\right), 3.74\left(\mathrm{~s}, 2 \mathrm{H},-\mathrm{COCH}_{2} \mathrm{COO}^{-}\right.$), $1.32-1.28\left(\mathrm{t}, 3 \mathrm{H}, J=8.0 \mathrm{~Hz},-\mathrm{CH}_{3}\right) ;{ }^{13} \mathrm{C} \mathrm{NMR}\left(\mathrm{CDCl}_{3}, 400\right.$ $\mathrm{MHz}) \delta_{\mathrm{c}}: 195.99\left(-\mathrm{COOCH}_{2} \mathrm{CH}_{3}\right), 167.53\left(-\mathrm{COCH}_{2} \mathrm{COO}^{-}\right)$, 78.27 ( $-\mathrm{CH}$ of $\mathrm{Fc}$ ), 72.95 ( $-\mathrm{CH}$ of $\mathrm{Fc}$ ), 70.09 ( $-\mathrm{CH}$ of Fc), 69.67 $(-\mathrm{CH}$ of $\mathrm{Fc}), 61.32\left(-\mathrm{COCH}_{2} \mathrm{COO}^{-}\right), 46.87\left(-\mathrm{COOCH}_{2} \mathrm{CH}_{3}\right)$, $14.20\left(-\mathrm{COOCH}_{2} \mathrm{CH}_{3}\right.$ ); MS (EI) $m / z: 301[\mathrm{M}+\mathrm{H}]^{+}$; Anal., Calcd. for $\mathrm{C}_{15} \mathrm{H}_{16} \mathrm{FeO}_{3}: \mathrm{C}, 60.03 \%$; H, 5.37\%. Found: C, 59.99\%; H, $5.52 \%$.

\subsubsection{6-Ferrocenylisocytosine (3)}

A suspension of guanidinium carbonate $(0.60 \mathrm{~g}, 3.33 \mathrm{mmol})$ and ethyl 3-ferrocenyl-3-oxopropionate $(1.65 \mathrm{~g}, 5.5 \mathrm{mmol})$ in absolute ethanol $(60 \mathrm{~mL})$ was refluxed overnight. After cooling to room temperature, the resultant clear, brown red solution was evaporated under vacuum and then $50 \mathrm{~mL}$ of $\mathrm{CHCl}_{3}$ was added. The organic layer was washed with brine, then dried with $\mathrm{Na}_{2} \mathrm{SO}_{4}$ for $12 \mathrm{~h}$, and concentrated to dryness. The crude was purified by performing column chromatography on silica gel $\left(\mathrm{CH}_{2} \mathrm{Cl}_{2} / \mathrm{CH}_{3} \mathrm{OH}, 10: 1(V / V)\right)$ to afford the product in $56 \%$ yield as red brown powder. ${ }^{1} \mathrm{H} \mathrm{NMR}$ $\left(\right.$ DMSO- $\left._{6}, 400 \mathrm{MHz}\right) \delta_{\mathrm{H}}: 10.53(\mathrm{~s}, 1 \mathrm{H},-\mathrm{C}=\mathrm{C}-\mathrm{OH}), 6.44(\mathrm{~s}$, $\left.2 \mathrm{H},-\mathrm{NH}_{2}\right), 5.79(\mathrm{~s}, 1 \mathrm{H},-\mathrm{C}=\mathrm{CH}-\mathrm{C}=\mathrm{N}), 4.82$ (br. s, 2H, Fc), 4.35 (br. s, 2H, Fc), 4.08 (br. s, $5 \mathrm{H}, \mathrm{Fc}$ ); ${ }^{13} \mathrm{C}$ NMR (d $\mathrm{d}_{6} \mathrm{DMSO}, 400$ MHz) $\delta_{\mathrm{c}}: 166.28\left(-\mathrm{C}=\mathrm{N}-\mathrm{C}-\mathrm{NH}_{2}\right), 155.20(\mathrm{FC}-\mathrm{C}-\mathrm{C}=\mathrm{C}-$ $\mathrm{OH}), 96.16(\mathrm{FC}-\mathrm{C}-\mathrm{C}=\mathrm{C}-\mathrm{OH}), 81.75(\mathrm{FC}-\mathrm{C}-\mathrm{C}=\mathrm{C}-\mathrm{OH})$, 69.87 ( $-\mathrm{CH}$ of $\mathrm{Fc}$ ), 69.51 ( $-\mathrm{CH}$ of $\mathrm{Fc}$ ), 67.60 ( $-\mathrm{CH}$ of $\mathrm{Fc}$ ); $\mathrm{MS}$ (EI) $m / z: 295[\mathrm{M}]^{-}$; Anal., Calcd. for $\mathrm{C}_{14} \mathrm{H}_{13} \mathrm{FeN}_{3} \mathrm{O}$ : C, 56.98\%; $\mathrm{H}$, $4.44 \%$; N, 14.24\%. Found: C, 56.80\%; H, 4.41\%; N, 14.29\%.

\section{2 .3 2-(4-Butyl)ureido-6-ferrocenyl-4[1H]-}

pyrimidinone (1)

A mixture of 6-ferrocenylisocytosine (3) (0.602 g, $2.04 \mathrm{mmol})$ and butylisocyanate $(0.449 \mathrm{~g}, 4.53 \mathrm{mmol})$ in dry pyridine $(30 \mathrm{~mL})$ was heated under reflux for $12 \mathrm{~h}$. After evaporating the solvent, the resultant residue was thoroughly washed with cold methanol, and then subjected to the purification by chromatography on silica gel $\left(\mathrm{CH}_{2} \mathrm{Cl}_{2} / \mathrm{MeOH}, 100: 1(\mathrm{~V} / \mathrm{V})\right)$ to afford the product as a yellow solid in $68 \%$ yield. ${ }^{1} \mathrm{H}$ NMR $\left(\mathrm{CDCl}_{3}, 400 \mathrm{MHz}\right) \delta_{\mathrm{H}}: 13.62(\mathrm{~s}, 1 \mathrm{H}$, $\mathrm{H}$ of intramolecular hydrogen bond), 12.03 (s, 1H, H of intermolecular hydrogen bond), 10.25 (s, $1 \mathrm{H}, \mathrm{H}$ of intermolecular hydrogen bond), 6.06 (s, 1H, $\mathrm{H}$ of 5-position of pyrimidinone), 4.72 (br. s, 2H, Fc), 4.50 (br. s, 2H, Fc), 4.23 (br. s, 5H, Fc), 3.34 (t, $\left.2 \mathrm{H}, J=8.0 \mathrm{~Hz},-\mathrm{CH}_{2} \mathrm{CH}_{2} \mathrm{CH}_{2} \mathrm{CH}_{3}\right), 1.45(\mathrm{~m}, 2 \mathrm{H}, J=8.0 \mathrm{~Hz}$, $\left.-\mathrm{CH}_{2} \mathrm{CH}_{2} \mathrm{CH}_{2} \mathrm{CH}_{3}\right), 1.26\left(\mathrm{~m}, 2 \mathrm{H}, J=8.0 \mathrm{~Hz},-\mathrm{CH}_{2} \mathrm{CH}_{2} \mathrm{CH}_{2} \mathrm{CH}_{3}\right)$, $\left.0.88(\mathrm{t}, 3 \mathrm{H}, J=8.0 \mathrm{~Hz})-,\mathrm{CH}_{2} \mathrm{CH}_{2} \mathrm{CH}_{2} \mathrm{CH}_{3}\right) ;{ }^{13} \mathrm{C} \mathrm{NMR}\left(\mathrm{CDCl}_{3}\right.$, $400 \mathrm{MHz}) \delta: 173.03\left(-\mathrm{NHCONH}^{-}\right), 156.81(-C=\mathrm{N}), 154.58$ $(\mathrm{Fc}-\mathrm{C}=\mathrm{C}-\mathrm{C}=\mathrm{O}), 150.80(\mathrm{Fc}-\mathrm{C}=\mathrm{C}-\mathrm{C}=\mathrm{O}), 101.64(\mathrm{Fc}-$ $C=\mathrm{C}-\mathrm{C}=\mathrm{O}), 74.23(-\mathrm{CH}$ of $\mathrm{Fc}), 71.28(-\mathrm{CH}$ of $\mathrm{Fc}), 70.39$ ( $-\mathrm{CH}$ of $\mathrm{Fc}), 66.75(-\mathrm{CH}$ of $\mathrm{Fc}), 39.93\left(-\mathrm{CH}_{2} \mathrm{CH}_{2} \mathrm{CH}_{2} \mathrm{CH}_{3}\right)$, $29.90\left(-\mathrm{CH}_{2} \mathrm{CH}_{2} \mathrm{CH}_{2} \mathrm{CH}_{3}\right), 20.26\left(-\mathrm{CH}_{2} \mathrm{CH}_{2} \mathrm{CH}_{2} \mathrm{CH}_{3}\right), 13.86$ ( $-\mathrm{CH}_{2} \mathrm{CH}_{2} \mathrm{CH}_{2} \mathrm{CH}_{3}$ ); MS (ESI) m/z: $395[\mathrm{M}+\mathrm{H}]^{+}$; Anal., Calcd. for $\mathrm{C}_{19} \mathrm{H}_{22} \mathrm{FeN}_{4} \mathrm{O}_{2}, \mathrm{C}, 57.88 \%$; H, 5.62\%; N, 14.21\%. Found: $\mathrm{C}$, $57.77 \%$; H, 5.69\%; N, 14.29\%.

\section{Results and discussion}

The preparations of key monomer for ferrocene dimer $\mathbf{1} \cdot \mathbf{1}$ are summarized in Fig.2. Briefly, treatment of acetylferrocene with diethyl carbonate in the presence of $\mathrm{NaH}$ afforded $\beta$-ketoester 2 as an intermediate, which was then reacted with guanidinium carbonate in refluxing absolute ethanol. After separation, the crude product 3 was reacted with $n$-butylisocyanate in pyridine to give compound $\mathbf{1}$ in good chemical yield.

${ }^{1}$ H NMR spectroscopy (Fig.3) clearly revealed that quadruple AADD hydrogen-bonded linked homodimer $\mathbf{1} \cdot \mathbf{1}$ was formed in $\mathrm{CDCl}_{3}$ because three hydrogen-bonded $\mathrm{NH}$ amide peaks (13.62, 12.03 , and 10.25) were observed at low field, which are in accordance with the reported resonance position for the $4[1 H]$-pyrimidinone tautomer ${ }^{24,25}$. Moreover, diluting compound $1 \mathrm{CDCl}_{3}$ solution to $1 \times 10^{-6} \mathrm{~mol} \cdot \mathrm{L}^{-1}$ did not lead to dissociation of proton resonance signals in the range from 10 to 14 . This shows that the binding constant can be as low as $10^{5} \mathrm{~L} \cdot \mathrm{mol}^{-1}$, which is consistent with the results from the reported similar compounds ${ }^{22,24}$.

The ${ }^{1} \mathrm{H}$ NMR titration experiment was progressed to comprehend the structural transformation of compound 1 in $\mathrm{CDCl}_{3}$ upon addition of protonic acid such as $\mathrm{CF}_{3} \mathrm{COOH}$. As shown in Fig.4, the stepwise addition of $\mathrm{CF}_{3} \mathrm{COOH}$ to a solution of $\mathbf{1}$ in $\mathrm{CDCl}_{3}$ resulted in three important changes in ${ }^{1} \mathrm{H}$ NMR spectra. Firstly, the gradual disappearance of the original signals for $\mathrm{H}^{\mathrm{a}}, \mathrm{H}^{\mathrm{b}}$, and $\mathrm{H}^{\mathrm{c}}$ occurred, accompanied by a concomitant reappearance of signals for $\mathrm{H}^{\mathrm{c}}$ at the high field. This showed that the dimer $\mathbf{1} \cdot \mathbf{1}$ was gradually dissociated due to protonation upon stepwise addition of $\mathrm{CF}_{3} \mathrm{COOH}$. When the molar ratio of $\mathrm{CF}_{3} \mathrm{COOH}$ to compound 1 was increased to $2: 1$ (Fig.4(e)), the signals associated with the formation of intermolecular hydrogen bonds $\left(\mathrm{H}^{\mathrm{b}}\right.$ and $\left.\mathrm{H}^{\mathrm{c}}\right)$ were almost vanished because of the dissociation of dimer $\mathbf{1} \cdot \mathbf{1}$. Sec-
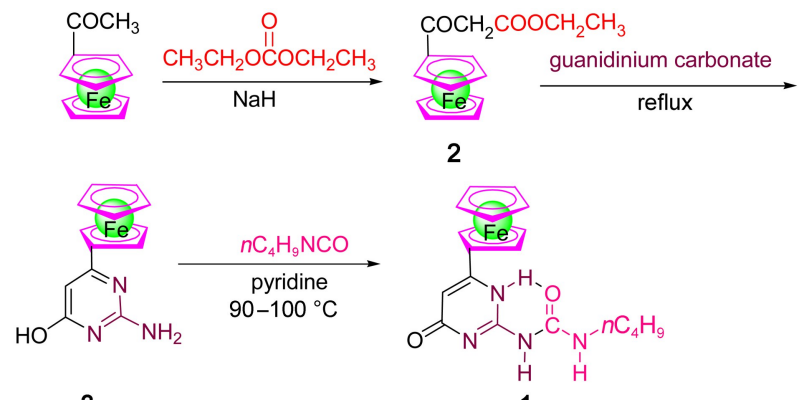

3

Fig.2 Synthetic route to compound 1

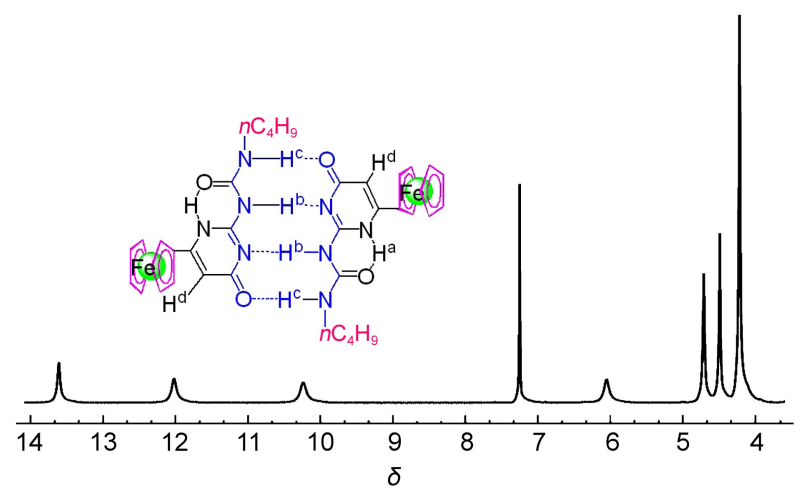

Fig.3 Partial ${ }^{1} \mathrm{H}$ NMR spectrum of compound 1 in $\mathrm{CDCl}_{3}$ 


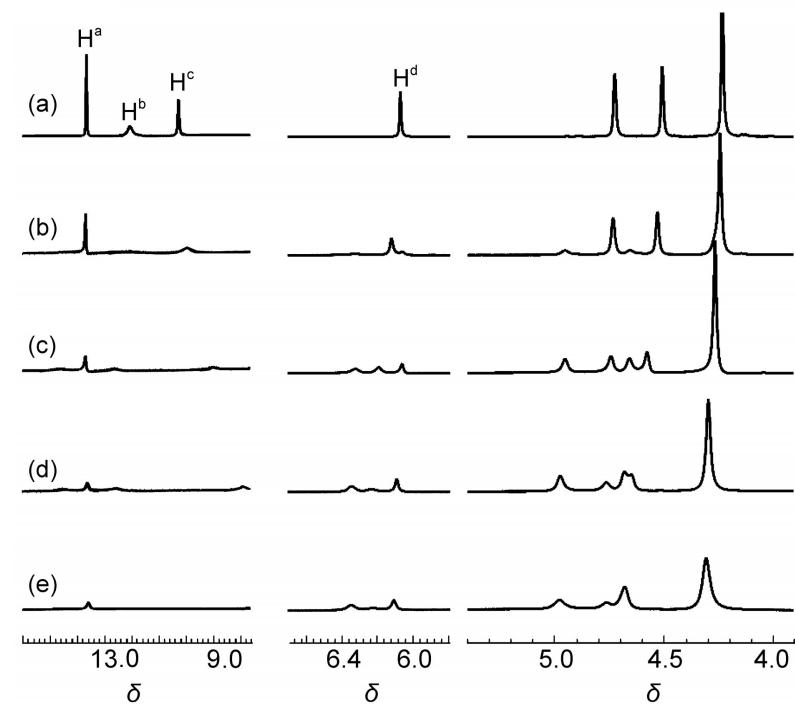

Fig.4 Partial ${ }^{1} \mathrm{H}$ NMR spectra of 1 in $\mathrm{CDCl}_{3}\left(5 \times 10^{-3} \mathrm{~mol} \cdot \mathrm{L}^{-1}\right)$ upon addition of (a) 0 , (b) 0.5 , (c) 1 , (d) 1.5,

(e) 2 equimolar $\mathrm{CF}_{3} \mathrm{COOH}$

ondly, with the addition of $\mathrm{CF}_{3} \mathrm{COOH}$ the singlet peak at 6.06 ascribed to $\mathrm{H}^{\mathrm{d}}$ of pyrimidinone ring was diminished and two new peaks were appeared at 6.34 and 6.12 (Fig.4). It is because some of the $4[1 H]$-pyrimidinone tautomer of 1 were converted to the pyrimidin-4-ol tautomeric form in the protonation process. As 2 equimolar $\mathrm{CF}_{3} \mathrm{COOH}$ was added to the solution of compound $\mathbf{1}$ in $\mathrm{CDCl}_{3}$, the integral area of the two peaks at 6.34 and 6.12 is equal, which indicated that equal amount of pyrimidinone and pyrimidin4-ol tautomer were present. Thirdly, the resonance signals for protons of the ferrocene moiety at $4-5$ were gradually downfield shifted because charge transfer from the ferrocene to the protonated pyrimidine ring occurred upon titration with $\mathrm{CF}_{3} \mathrm{COOH}$. From above results, it can be seen that addition of $\mathrm{CF}_{3} \mathrm{COOH}$ leads to the protonation-induced dissociation of dimer $\mathbf{1} \cdot \mathbf{1}$, accompanied by the $50 \%$ transformation from $4[1 H]$-pyrimidinone to pyrimidin4-ol tautomer (Fig.5), which caused the changes of the microenvironment of ferrocene protons. In addition, 2 equimolar $\mathrm{CF}_{3} \mathrm{COOH}$ can cause the full dissociation of dimer $\mathbf{1} \cdot \mathbf{1}$. The addition equimolar amount of the $\mathrm{Et}_{3} \mathrm{~N}$ in above solution can lead to the complete recovery of the initial spectrum (Supporting Information). This showed the good reversibility of disassociation of dimer $\mathbf{1} \cdot \mathbf{1}$.
The UV-Vis titration spectra of compound $\mathbf{1}$ in $\mathrm{CHCl}_{3}$ were also performed to demonstrate the reversible protonation/deprotonation process. As shown in the Fig.6a, the UV-Vis absorption spectrum of compound 1 showed an intense $\pi-\pi^{*}$ absorption band at 293 and a weak low energy band attributable to the $d-d$ transition arising from the ferrocene unit at $456 \mathrm{~nm}$. Upon titration with $\mathrm{CF}_{3} \mathrm{COOH}$ (Fig.6a to Fig.6e), both absorption bands were red-shifted because charge transfer from the ferrocene to the protonated pyrimidine heterocycle occurred. The change was completed with the addition of 2 equimolar acid which further proved that the reaction molar ratio of $\mathrm{CF}_{3} \mathrm{COOH}$ to compound 1 was $1: 2$. Afterwards adding equimolar amount of the $\mathrm{Et}_{3} \mathrm{~N}$ could also make the initial UV-Vis spectrum recover, which indicates that the protonation/deprotonation of compound $\mathbf{1}$ is well reversible, similar to the case of ${ }^{1} \mathrm{H}$ NMR experiment (Supporting Information).

The redox behavior of the ferrocene dimer $\mathbf{1} \cdot \mathbf{1}$ was examined in chloroform. The cyclic voltammogram (CV) of homodimer $\mathbf{1}$. 1 (Fig.7(a)) well displays two separated oxidation waves at 0.27 and $0.53 \mathrm{~V}$ ( $v s \mathrm{SCE}$ ). In general, functional molecules possessing multiple redox sites such as ferrocene groups can exhibit just a single redox peak even if the redox active sites are electronically isolated. However, in the case electronic coupling exists across the redox sites, they may be influenced by each other, which routinely makes the single redox potential separated into several different redox peaks. The value between the separated oxidation potentials $(\Delta E)$ can be considered as a guide to the magnitude of the electronic communication ${ }^{26}$. Thus in homodimer $\mathbf{1} \cdot \mathbf{1}$ the separation of the oxidation waves indicates the existence of a remarkable level of electronic communication between the two ferrocene groups, with a large value of $\Delta E(260 \mathrm{mV})$ in $\mathrm{CHCl}_{3}$. With respect to the crystal structure of self-complementary quadruple hydrogenbinded unit of 2-ureido- $4[1 H]$-pyrimidinone motif ${ }^{22,24}$, the ferrocene group in dimer $\mathbf{1} \cdot \mathbf{1}$ should have the side-by-side arrangement with edge-to-edge separation of $1 \mathrm{~nm}$. In such a configuration, the two ferrocene groups were stabilized mainly by the directionality and rigidity of the hydrogen-bonded unit used here, which inhibit the electronic communication between the ferrocene groups via the through space mechanism. Therefore, the electronic communication between the ferrocene groups in homodimer $\mathbf{1} \cdot \mathbf{1}$ should occur across 2-ureido-4[1H]-pyrimidinone hydrogenbonded interface.
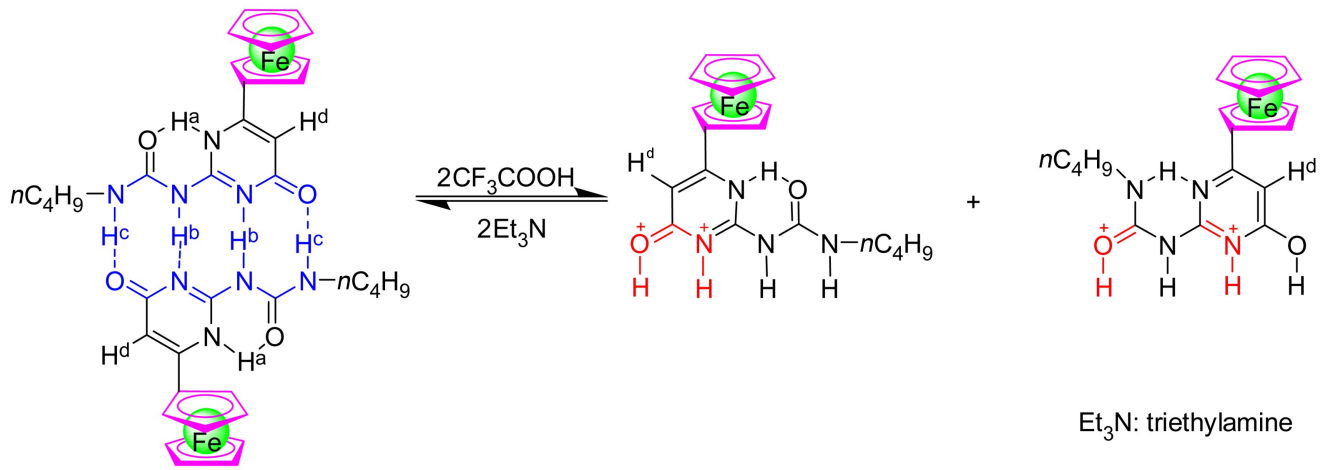

$\mathrm{Et}_{3} \mathrm{~N}$ : triethylamine

Fig.5 Structural transformation of compound 1 upon addition of $\mathrm{CF}_{3} \mathrm{COOH} / \mathrm{Et}_{3} \mathrm{~N}$ in $\mathrm{CDCl}_{3}$ 


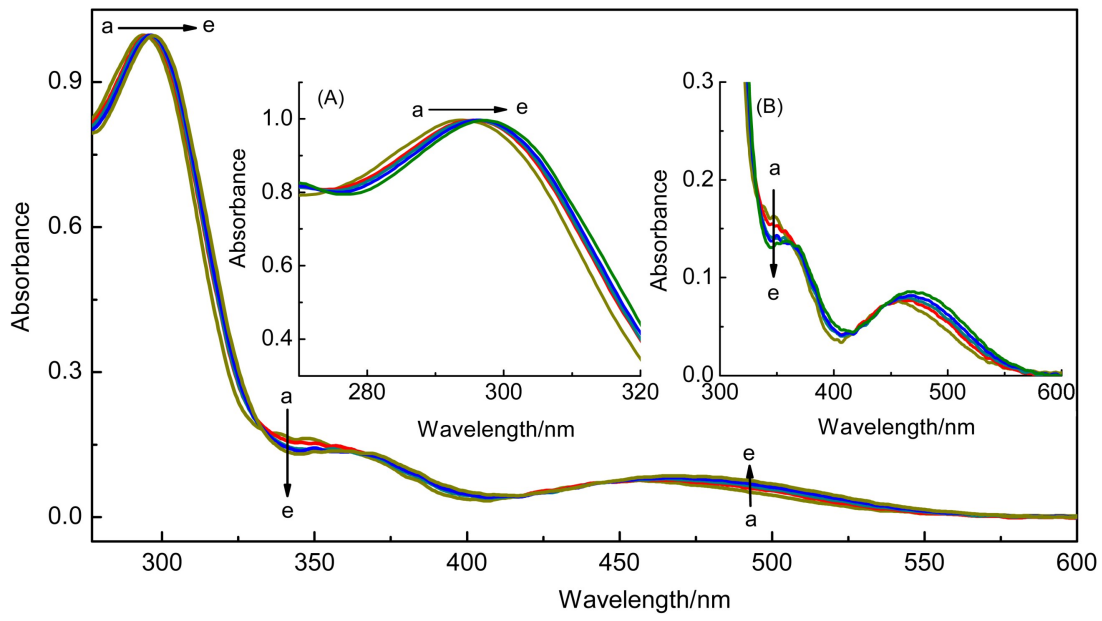

Fig.6 Absorption spectral changes of compound $1\left(4 \times 10^{-5} \mathrm{~mol} \cdot \mathrm{L}^{-1}\right)$ in $\mathrm{CHCl}_{3}$ upon addition of $\mathrm{CF}_{3} \mathrm{COOH}$ From curve a to curve e, the concentration of $\mathrm{CF}_{3} \mathrm{COOH}$ increases from 0 to $2 \times 10^{-5}, 4 \times 10^{-5}, 6 \times 10^{-5}$, and $8 \times 10^{-5} \mathrm{~mol} \cdot \mathrm{L}^{-1}$, respectively. Insets show the partial magnified figure of the absorption spectra of compound $\mathbf{1}$.

Because the electronic communication in dimer $\mathbf{1} \cdot \mathbf{1}$ occurs through the quadruple hydrogen-bondde interface, it was expected that the electronic communication can also be controlled by addition of $\mathrm{CF}_{3} \mathrm{COOH} / \mathrm{Et}_{3} \mathrm{~N}$, considering that the quadruple hydrogen bonds of homodimer $\mathbf{1} \cdot \mathbf{1}$ can be gradually dissociated/associated upon titration with $\mathrm{CF}_{3} \mathrm{COOH} / \mathrm{Et}_{3} \mathrm{~N}$ in $\mathrm{CHCl}_{3}$ as evidenced by ${ }^{1} \mathrm{H}$ NMR spectra. From the cyclic voltammetry shown in Fig.7, upon addition of 0.5 equimolar of $\mathrm{CF}_{3} \mathrm{COOH}$, the $\Delta E$ representing the magnitude of electronic communication was decreased from 260 $\mathrm{mV}$ (Fig.7a) to $150 \mathrm{mV}$ (Fig.7b), and was further reduced to 100 $\mathrm{mV}$ when the molar ratio of $\mathrm{CF}_{3} \mathrm{COOH}$ to compound 1 was increased to $1: 1$, because of the partial dissociation of the quadruple hydrogen-bonded bridge by the successive addition of $\mathrm{CF}_{3} \mathrm{COOH}$. When the molar ratio of $\mathrm{CF}_{3} \mathrm{COOH}$ to compound $\mathbf{1}$ was increased to $2: 1$, the two separated oxidation waves were integrated into one new wave at $0.41 \mathrm{~V}$ with the $\Delta E$ of $0 \mathrm{mV}$
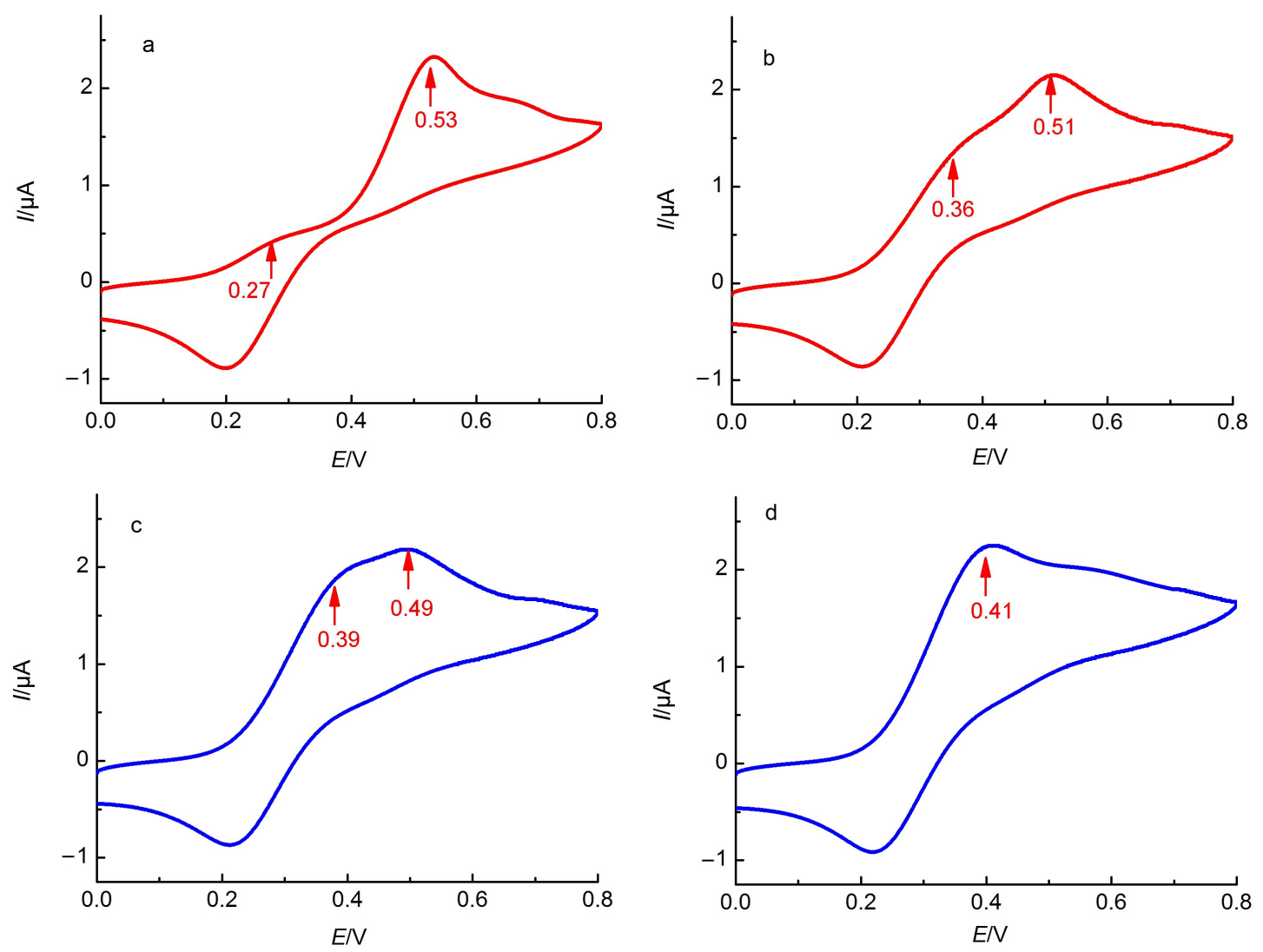

Fig.7 Cyclic voltammogram curves of $1\left(4 \times 10^{-4} \mathrm{~mol} \cdot \mathrm{L}^{-1}\right)$ in $\mathrm{CHCl}_{3}$ upon addition of (a) 0, (b) 0.5 , (c) 1 , (d) 2 equimolar $\mathrm{CF}_{3} \mathrm{COOH}$ The working and counter electrodes were all Pt slide, the reference electrode was SCE; scan rate was $100 \mathrm{mV} \cdot \mathrm{s}^{-1}$ 
(Fig.7d). This is because the electronic communication between the ferrocenes units was effectively inhibited due to the completely destroying of quadruple hydrogen-bonded bridge and dissociation of homodimer $\mathbf{1} \cdot \mathbf{1}$. In addition, above phenomenon is highly reversible, the initial voltammogram can be stepwise recovered by successive addition of $\mathrm{Et}_{3} \mathrm{~N}$ (Supporting Information). This shows that the stepwise association-dissociation of homodimer $\mathbf{1} \mathbf{1}$ by reversible protonation/deprotonation process can be used to tune the level of electronic communication effectively.

\section{Conclusions}

In summary, in this paper an ureidopyrimidinone modified ferrocene derivative that self-assembled into stable hydrogenbonded ferrocene dimer in polar solvent $\mathrm{CHCl}_{3}$ and $\mathrm{CH}_{2} \mathrm{Cl}_{2}$ was prepared. The assembled ferrocene dimer shows controllable behavior of the electronic communication by protonation of the pyrimidinone unit. The $\mathrm{CV}$ data of the hydrogen-bonded dimer in $\mathrm{CHCl}_{3}$ showed splitting of the oxidative waves of the ferrocene centers, revealing the existence of electronic communication across hydrogen-bonded bridge. Upon protonation/deprotonation, the electronic communication of the two ferrocene units was gradually switched off/on due to the controllable dissociation/ association of the hydrogen-bonded dimer. The high reversibility and great binding strength of the ureidopyrimidinone hydrogenbonded unit play the important role in the formation of a controllable conversion system of redox-protonation coupled reaction. Further utilization of the ureidopyrimidinone hydrogen-bonded unit as bridge may comprise a new chemistry of mixed-valence system.

Supporting Information: available free of charge via the internet at http://www.whxb.pku.edu.cn.

\section{References}

(1) Venkatasubbaiah, K.; Zakharov, L. N.; Kassel, W. S.; Rheingold, A. L.; Jäkle, F. Angew. Chem. 2005, 117 (34), 5564. doi: 10.1002/ange.200502148

(2) Nishihara, H. Bull. Chem. Soc. Jpn. 2001, 74 (1), 19. doi: 10.1246/bcsj.74.19

(3) Ceccon, A.; Santi, S.; Orian, L.; Bisello, A. Coordin. Chem. Rev. 2004, 248, 683. doi:10.1016/j.ccr.2004.02.007

(4) Muraoka, H.; Watanabe, Y.; Takahashi, A.; Kamoto, H.; Ogawa, S. Heteroatom Chem. 2014, 25, 473. doi: 10.1002/ hc. 21156

(5) Xu, G. L.; Crutchley, R. J.; DeRosa, M. C.; Pan, Q. J.; Zhang, H. X.; Wang, X.; Ren, T. J. Am. Chem. Soc. 2005, 127 (38), 13354. doi: $10.1021 / \mathrm{ja} 0534452$

(6) Xu, G. L.; Xi, B.; Updegraff, J. B.; Protasiewicz, J. D.; Ren, T. Organometallics 2006, 25 (22), 5213. doi: 10.1021/om0607550

(7) Iyoda, M.; Kondo, T.; Okabe, T.; Matsuyama, H.; Sasaki, S.;
Kuwatani, Y. Chem Lett. 1997, 26 (1), 35. doi: 10.1246/ cl.1997.35

(8) Li, Y.; Josowicz, M.; Tolbert, L. M. J. Am. Chem. Soc. 2010, 132 (30), 10374. doi: 10.102/ja101585z

(9) Hu, Y. Q.; Zhu, N.; Han, L. M. Acta Phys. -Chim. Sin. 2015, 31 (2), 227. [胡宇强, 竺 宁, 韩利民. 物理化学学报, 2015, 31 (2), 227.] doi: 10.3866/PKU.WHXB201411061

(10) Mahmoud, K.; Long, Y. T.; Schatte, G.; Kraatz, H. B. J. Organomet. Chem. 2004, 689, 2250. doi: 10.1016/j. jorganchem.2004.04.016

(11) Yoshida, J.; Kuwahara, K.; Yuge, H. J. Organomet. Chem. 2014, 756, 19. doi: 10.1016/j.jorganchem.2014.01.018

(12) Tanaka, Y.; Koike, T.; Akita, M. Eur. J. Inorg. Chem. 2010, 3571. doi: 10.1002/ejic.201000661

(13) Moriuchi, T.; Hirao, T. Tetrahedron Lett. 2007, 48 (29), 5099. doi: 10.1016/j.tetlet.2007.05.095

(14) Di Pietro, C. D.; Serroni, S.; Campagna, S.; Gandolfi, M. T.; Ballardini, R.; Fanni, S.; Browne, W. R.; Vos, J. G. Inorg. Chem. 2002, 41 (11), 2871. doi: 10.1021/ic0112894

(15) Alvarez, J.; Kaifer, A. E. Organometallics 1999, 18 (26), 5733. doi: $10.1021 / 0 m 990678 \mathrm{r}$

(16) Tannai, H.; Tsuge, K.; Sasaki, Y. Inorg. Chem. 2005, 44 (15), 5206. doi: 10.1021/ic050672w

(17) de Rege, P. J.; Williams, S. A.; Therien, M. J. Science 1995, 269, 1409. doi: 10.1126/science.7660123

(18) Sánchez, L.; Sierra, M.; Martín, N.; Myles, A. J.; Dale, T. J.; Rebek, J.; Seitz, W.; Guldi, D. M. Angew. Chem. Int. Edit. 2006, 45 (28), 4637. doi: 10.1002/anie.200601264

(19) Wilkinson, L. A.; McNeill, L.; Meijer, A. J. H. M.; Patmore, N. J. J. Am. Chem. Soc. 2013, 135 (5), 1723. doi: 10.1021/ ja312176x

(20) Goeltz, J. C.; Kubiak, C. P. J. Am. Chem. Soc. 2010, 132 (49), 17390. doi: $10.1021 / \mathrm{ja} 108841 \mathrm{k}$

(21) Sun, H.; Steeb, J.; Kaifer, A. E. J. Am. Chem. Soc. 2006, 128 (9), 2820. doi: 10.1021/ja060386z

(22) Beijer, F. H.; Sijbesma, R. P.; Kooijman, H.; Spek, A. L.; Meijer, E. W. J. Am. Chem. Soc. 1998, 120 (27), 6761. doi: 10.1021/ja974112a

(23) Sijbesma, R. P.; Meijer, E. W. Chem. Commun. 2003, 5. doi: 10.1039/B205873C

(24) Alexander, A. M.; Bria, M.; Brunklaus, G.; Caldwell, S.; Cooke, G.; Garety, J. F.; Hewage, S. G.; Hocquel, Y.; McDonald, N.; Rabani, G.; Rosair, G.; Smith, B. O.; Spiess, H. W.; Rotello V. M.; Woisel, P. Chem. Commun. 2007, 2246. doi: 10.1039/B703070C

(25) Zhao, Y. P.; Zhao, C. C.; Wu, L. Z.; Zhang, L. P.; Tung, C. H.; Pan, Y. J. J. Org. Chem. 2006, 71 (5), 2143. doi: 10.1021/ jo051932u

(26) Demadis, K. D.; Hartshorn, C. M.; Meyer, T. J. Chem. Rev. 2001, 101 (9), 2655. doi: 10.1021/cr990413m 
Supporting Information for Acta Phys. -Chim. Sin. 2016, 32 (3), 611-616 doi: $10.3866 /$ PKU.WHXB201601044

\title{
腿基嘧啶酮四氢键二茂铁二聚体：电子相互作用的调控
}

王素敏 赵线娜 王奇观 ${ }^{*}$ 郭浩 李金华 张文慧 (西安工业大学材料与化工学院, 陕西省光电功能材料与器件重点实验室, 西安 710032)

\section{Ureidopyrimidinone Quadruple Hydrogen-Bonded Ferrocene Dimer: Control of Electronic Communication}

\author{
WANG Su-Min \\ ZHAO Rong-Na \\ WANG Qi-Guan* \\ GUO Hao \\ LI Jin-Hua \\ ZHANGWen-Hui
}

(Shaanxi Key Laboratory of Photoelectric Functional Materials and Devices, School of Materials and Chemical Engineering, Xi'an Technological University, Xi'an 710032, P. R. China)

*Corresponding author. Email: qiguanwang@163.com; Tel: +86-29-86173324. 

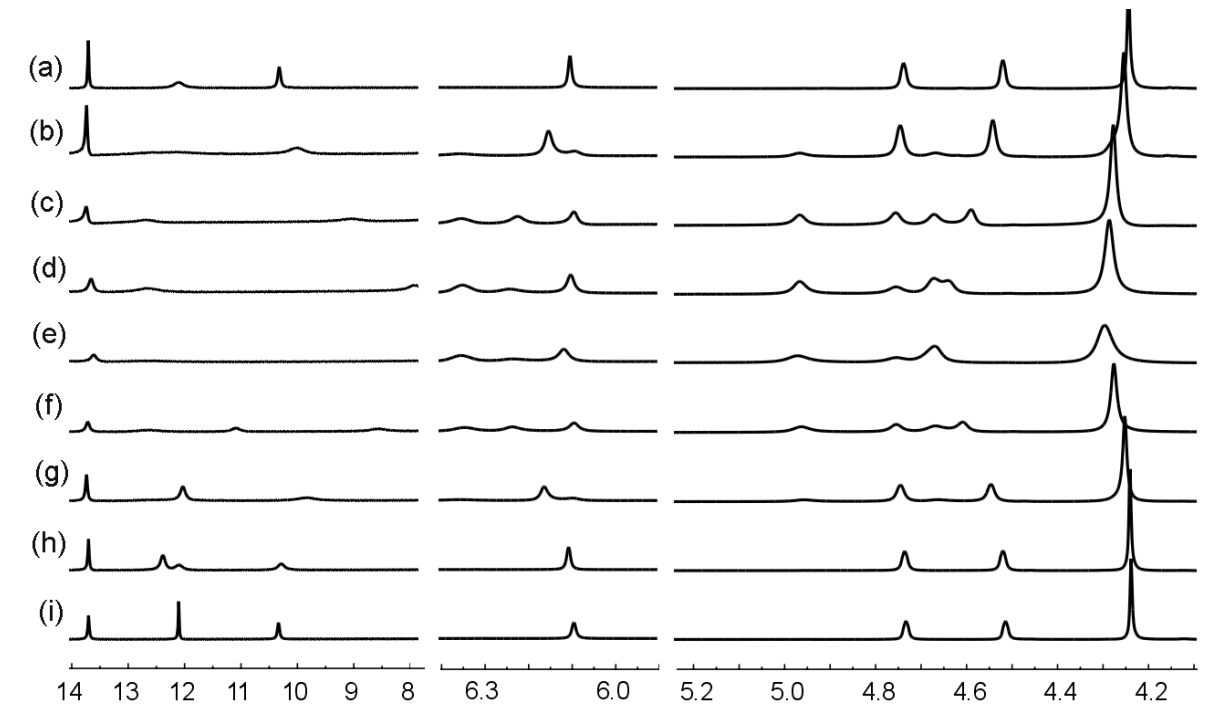

Fig.S1 ${ }^{1} \mathrm{H}$ NMR spectra of 1 in $\operatorname{CDCl}_{3}\left(5 \times 10^{-3} \mathrm{~mol} \cdot \mathrm{L}^{-1}\right)$ upon addition of (a) 0 , (b) 0.5, (c) 1.0, (d) 1.5, (e) 2.0 equiv. molar of $\mathrm{CF}_{3} \mathrm{COOH}$ and then (f) 0.5, (g) 1.0, (h) 1.5, (i) 2.0 equiv molar of triethylamine $\left(\mathrm{Et}_{3} \mathrm{~N}\right)$

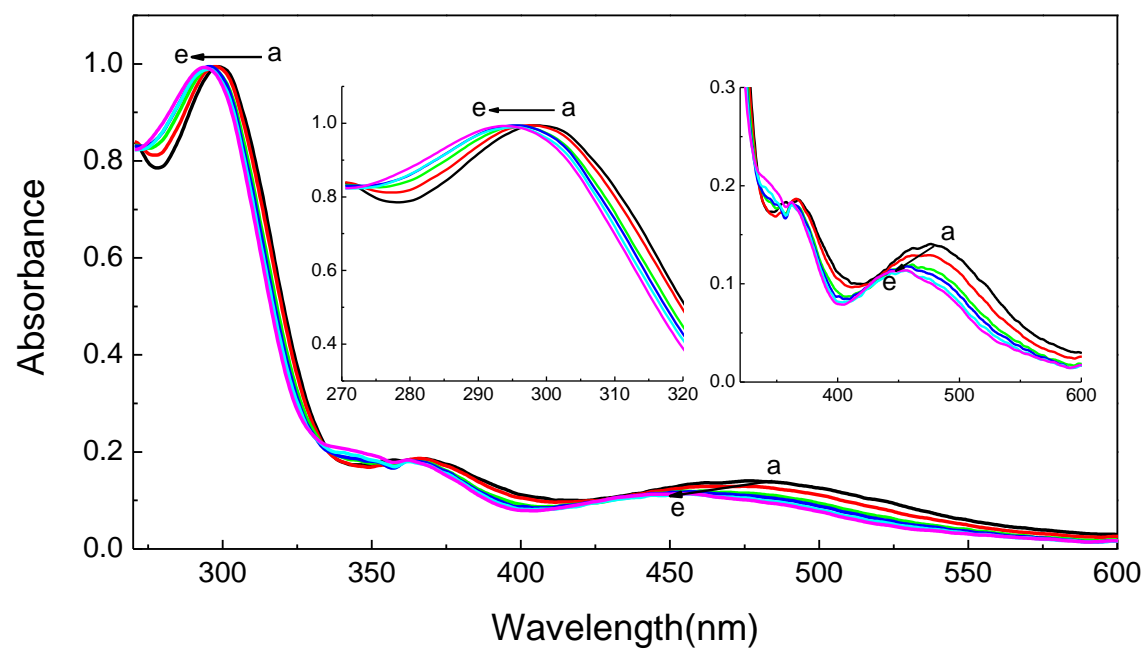

Fig.S2 Absorption spectral changes of compound $1\left(4 \times 10^{-5} \mathrm{~mol} \cdot \mathrm{L}^{-1}\right)$ and $\mathrm{CF}_{3} \mathrm{COOH}\left(8 \times 10^{-5} \mathrm{~mol} \cdot \mathrm{L}^{-1}\right)$ in $\mathrm{CHCl}_{3}$ upon addition of $\mathrm{Et}_{3} \mathrm{~N}$

From line a to line e, the concentration of $\mathrm{Et}_{3} \mathrm{~N}$ increased from 0 to $8 \times 10^{-5} \mathrm{~mol} \cdot \mathrm{L}^{-1}$. Inset: the partial magnified figure of the absorption spectra of compound $\mathbf{1}$ 

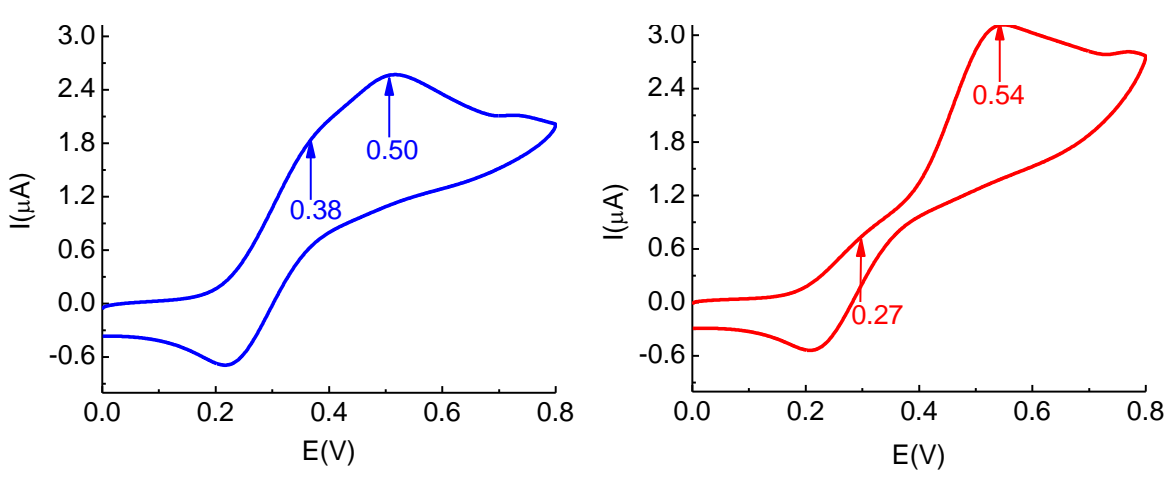

Fig.S3 Cyclic voltammograms of $1\left(4 \times 10^{-4} \mathrm{~mol} \cdot \mathrm{L}^{-1}\right)$ and $\mathrm{CF}_{3} \mathrm{COOH}\left(8 \times 10^{-4}\right.$ mol· $\mathrm{L}^{-1}$ ) in $\mathrm{CHCl}_{3}$ solution upon addition of (a) 1.0, (b) 2.0 equiv molar of $\mathrm{Et}_{3} \mathrm{~N}$

The working and counter electrode were all Pt wire, the reference electrode was SCE, and the scan rate was $100 \mathrm{mV} \cdot \mathrm{s}^{-1}$. 